\title{
Rancangan dan Respons Aktifitas pada Taman Musik Kota Bandung
}

\author{
Eka Virdianti dan Dian Duhita \\ Jurusan Arsitektur, Fakultas Teknik Sipil dan Perencanaan, ITENAS, Bandung \\ Jl. PKH. Mustapha No. 23, Bandung 40124 \\ Email: virdianti_eka@itenas.ac.id
}

\begin{abstract}
ABSTRAK
Tematik merupakan salah satu pendekatan responsif yang mempermudah perancang untuk menemukan identitas karya. Taman adalah ruang publik terbuka yang berfungsi sebagai tempat berkumpul komunitas dan penyeimbang iklim mikro lingkungan. Periode 2014, Kota Bandung mencoba menghidupkan taman sebagai ruang publik kota dengan memberikan identitas tematik dan menyediakan elemen/fitur taman yang menarik. Obyek penelitian merupakan Taman yang dipilih karena tema taman mewakili segmentasi umur komunitas muda-mudi kota. Tujuan penelitian ini adalah menganalisis penerapan disain responsif dan respon aktifitas komunitas di Taman Musik. Penelitian menggunakan pendekatan kualitatif dengan partisipasi-observasi dan metoda analisis deskriptif. Hasil kesimpulan memberikan gambaran bahwa Taman Musik memiliki rancangan yang cukup sesuai dengan tema dan menghasilkan jenis respons yang berbeda. Taman tersebut telah memberikan rancangan yang cukup menarik sehingga mengundang komunitas kota untuk datang ke taman namun pengunjung merespon dengan aktifitas yang tidak sesuai tema.
\end{abstract}

Kata Kunci: Rancangan, Tematik, Respon Aktifitas

\begin{abstract}
The Thematic is one of responsive approach to help an architect to find identity of their design. A Park is open public spaces which has a function as community gathering place and balance the micro climate. At period 2014, Bandung tried to activated the park as public space by giving the new thematic identity and provide attractive element/features. The Object of study was selected by segmentation thematic community which represented adult of city community. The aim of study is analyzing implementation of responsive design and activities community responses in Taman Music. This study use a qualitative approach with participatory observation and descriptive analitic method. The conclucion describe are Taman Music designed pretty appropriate to the theme and generate the differences respons. These park presented attractive design which invite the adult community to activating in that area. Although the community activity responses is distinct with the theme.
\end{abstract}

Keywords: Design, Thematic, Activity Responses 


\section{PENDAHULUAN}

Taman sebagai ruang publik dapat digambarkan sebagai ruang komunal skala kota dimana masyarakat kota berkunjung sebagai teman, tetangga dan warga kota. Tempat ini memberikan keutamaan untuk kegiatan interaksi antara individu dan antar kultur. Ruang publik menyediakan sesuatu yang menarik secara visual, pengalaman dan perbedaan aktivitas. Aktifitas yang terjadi dalam tempat tersebut menciptakan komunikasi antara lingkungan dan komunitas kota [1].

Terdapat beberapa kriteria keberhasilan ruang publik pada skala aktivitas kota antara lain merupakan kombinasi dari 3 variabel utama yang membentuk makna sebuah tempat, yakni activity, image dan form [2]. Hasil dari kombinasi ketiga faktor tersebut adalah beberapa atribut keberhasilan sebuah ruang publik menjadi tempat yang bermakna, dua diantaranya yaitu comfort and image, dan uses and activity.

Pemerintah Kota Bandung mencoba untuk menghidupkan komunitas-komunitas warga kota melalui kegiatan interaksi dalam ruang publik. Melalui disain Taman, Pemerintah Kota bertujuan memberikan tempat untuk berkegiatan aktif, berkreasi dan berproduksi [3] dimana tempat tersebut diharapkan menciptakan komunikasi antara lingkungan dan komunitas kota. Sebelum dilakukan renovasi, beberapa taman di kota Bandung menjadi rancangan pasif tanpa interaksi komunitas hanya pemberi kenyamanan termal kawasan.

Taman dengan rancangan tematik berbasis komunitas diterapkan di beberapa taman kota Bandung sebagai salah satu langkah untuk mengaktifkan fungsi-kegiatan taman. Sebagian dari komunitas kota dijadikan identitas dan tema dari nama Taman Kota. Pada kriteria disain berbasis komunitas dikatakan bahwa "Identifikasi aspek arsitektur berbasis komunitas melalui metode dengan penampil yang mendefinisikan dan mengarahkan dirinya sendiri dalam ruang yang diberikan" [4]. Sisi identitas taman tematik harus direpresentasikan pada sisi penampil dan ruang yang dirancang. Penampil arsitektur dapat diwujudkan dalam elemen pembentuk Taman sebagai bagian dari atribut keberhasilan sisi comfort and image. Secara umum pada teori landscape, terdapat dua kategori elemen pembentuk taman yaitu: (1) Hardscapes yang dapat diidentifikasi dengan sesuatu yang dibuat oleh bahan keras, (2) Softscapes yaitu berlawanan unsur yang sebelumnya, elemen ini terdiri dari hal hidup.

Bentuk keberhasilan ruang public lainnya adalah uses and activity. Dari hal tersebut terlihat tautan antara disain dan aktifitas yang merepresentasikan identitas dan tema rancangan Taman. Faktanya, beberapa taman tematik di Kota Bandung memiliki fitur dominan yang bersifat spesifik dan terdefinisikan dengan baik, walaupun di beberapa tempat tidak sesuai dengan identitas taman. Fitur dominan yang menarik mengundang komunitas kota untuk berkunjung. Namun dari tiga tujuan penyediaan taman kota Bandung, hanya tercapai pada kegiatan aktif. Untuk tujuan kegiatan kreatifitas dan produktifitas belum tercapai [5].

Taman Musik merupakan salah satu taman dengan identitas baru sebagai tempat bermain musik. Namun apakah rancangan beridentitas Taman Musik tersebut telah menyediakan elemen disain penampil yang memberikan stimulan sehingga direspon oleh komunitas kota dalam bentuk aktifitas. Penelitian ini bertujuan untuk menganalisis rancangan responsif Taman Musik dan respon aktifitas komunitas kota.

\section{METODOLOGI}

Obyek penelitian dipilih Taman Musik dengan pertimbangan segmentasi komunitas muda-mudi Bandung, direncanakan untuk pengembangan kreatifitas bermusik. Lingkup penelitian berupa beberapa kriteria dari 7 (tujuh) variabel disain responsif [6] yang berkaitan langsung dengan comfort and image dan uses and activity [2], yaitu: (1) Robustness, ada ruang-ruang temporal, dapat difungsikan untuk berbagai aktivitas yang berbeda pada waktu yang berbeda. (2) Visual Approriate, mampu mengidentifikasi fungsi bangunan dengan melihat fisiknya (3) Personalization, melibatkan partisipasi komunitas serta adanya interaksi antara manusia dan lingkungan. 
Penelitian ini menggunakan pendekatan kualitatif dengan metoda pengambilan data partisipatory observation. Data diambil oleh dua tim yang berbeda, tim pertama melakukan observasi dan dokumentasi, tim kedua melakukan wawancara pada responden terpilih. Responden diambil secara purposive sampling dimana partisipan diambil secara acak sesuai pertimbangan observer.Target sampel wawancara pada masing-masing waktu observasi adalah 5 (lima) responden. Waktu observasi diambil pada perkiraan peak time pada saat weekday yaitu 11:00-15:00WIB dan weekend pada saat pagi dan sore yaitu 08:00-10:00 and 15:00 -16.00WIB. Data berupa pengamatan obyektif berdasarkan observer dan data wawancara bersifat subyektif yaitu pengunjung yang berlaku sebagai responden. Data-data tersebut dianalisis dengan metode deskriptif.

\subsection{Identitas Taman Musik}

\section{HASIL DAN DISKUSI}

Taman Musik dikenal juga dengan nama Taman Centrum, terletak di depan (dahulu) Area Permandian Centrum yang sekarang telah beralih fungsi menjadi Café. Berlokasi di jalan Belitung, luas Taman Musik berkisar $+2000 \mathrm{~m} 2$ (Peta Garis Kota Bandung), sebelumnya merupakan taman yang sudah beberapa kali dilakukan renovasi, tahun 2014 dilakukan renovasi kedua dengan mengusung tema musik, dapat dilihat pada gambar 1

Keberadaan Taman musik diharapkan digunakan untuk anak-anak muda Bandung dalam mengembangkan kreatifitas dalam bermusik. Tempat itu bisa jadi tempat bagi band musik yang ingin tampil dan bisa digunakan dengan gratis. Persyaratan melalui koordinasi dengan DISKAMTAM Bandung dan Pihak Kepolisian [7].

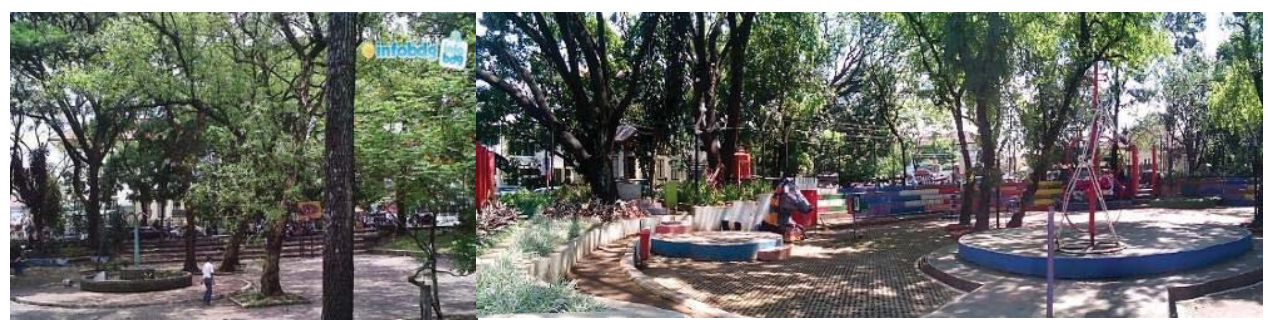

(a)

(b)

Gambar 1 (a)Kondisi Sebelum Renovasi [9], (b) Kondisi Sesudah Renovasi

Dari hasil pengamatan dapat dideskripsikan seperti dilihat pada gambar 2 yaitu: (1) Zona Stage : Zona ini berfungsi sebagai stage/panggung. Berbentuk lingkaran dengan elevasi ketinggian yang berbeda sekitar $20 \mathrm{~cm}$. Jumlah stage ada 3 (tiga), namun hanya dua yang dapat dipergunakan untuk panggung. (2) Zona Amphiteather: merupakan area tangga yang dapat digunakan sebagai tempat duduk, dirancang melingkar menghadap stage/panggung. (3) Zona Hijau: Area ini merupakan tempat elemen softscape taman berupa pepohonan perdu dan bertajuk sedang. (4) Zona Lapangan Basket Mini: Area ini berada dilengkapi dengan dua ring basket, material perkerasan berupa beton.

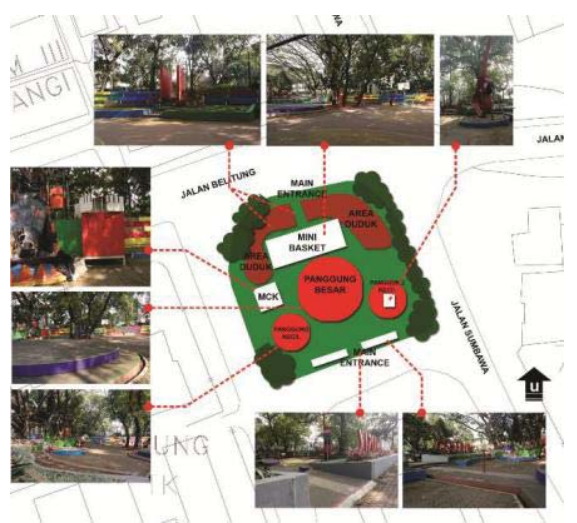

Gambar 2 Pembagian Zona Pada Taman Musik 
Pembagian zona pada Taman Musik secara luasan didominasi pada center taman yaitu area stage. Untuk lingkup batas site/area periferi sebagian digunakan untuk amphitheater, hal tersebut memanfaatkan adanya perbedaan elevasi antara bagian elevasi tengah taman dan jalan sebelah utara, timur dan barat.

\subsection{Rancangan Responsif}

\subsubsection{Robustness}

Kriteria ini difokuskan pada penyediaan ruang-ruang temporal, dapat difungsikan untuk berbagai aktivitas yang berbeda pada waktu yang berbeda. Taman Musik, memiliki disain yang terbuka dan terdapat zona berbeda, dari sisi batasan zona serta fitur sangat sederhana. Penyebaran area hijau tidak terlalu dominan di area tengah sehingga dari sisi fungsi, sehingga dapat berfungsi untuk kegiatan yang beragam, lihat gambar 3 .
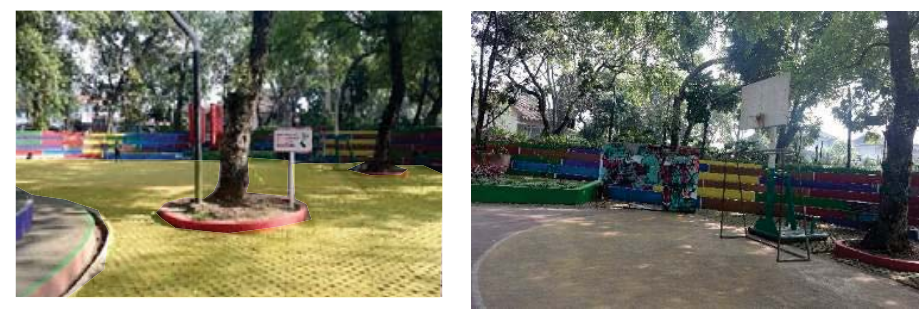

Gambar 3 Zona Taman dirancang dengan Fleksibilitas Fungsi

Dari hasil pengamatan, Taman Musik telah menyediakan ruang/area yang dirancang dengan fungsi khusus namun bersifat fleksibel untuk berbagai aktifitas. Seperti zona basket, difungsikan sebagai tempat bermain basket, aktifitas aktif lainnya sampai dengan untuk penempatan booth acara tertentu.

\subsubsection{Visual Appropriate}

Komponen ini dipertimbangkan agar pengunjung mampu mengidentifikasi fungsi bangunan dengan melihat fisiknya Taman Musik berfungsi sebagai taman, ruang interaksi dan perform acara music. Tatanan hardscape dan softscape memenuhi untuk fungsi taman, seperti tergambar pada gambar 4 . .

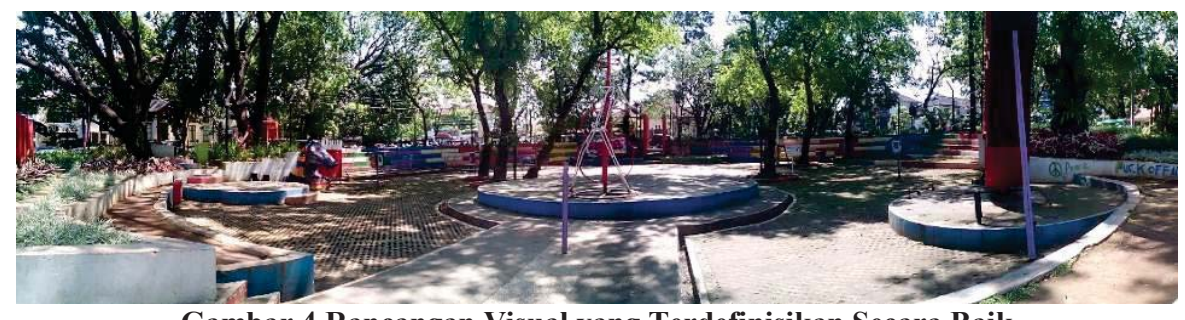

Gambar 4 Rancangan Visual yang Terdefinisikan Secara Baik

Dari sisi fisik rancangan, taman ini dapat diidentifikasi dengan baik sebagai taman dan ruang publik.Fungsi taman teridentifikasi dengan elemen tanaman hidup dengan tajuk pohon yang besar, memberikan kenyamanan termal. Fungsi Publik teridentifikasi dengan rancangan terbuka dan area duduk. Dari sisi identitas-tema, diwakili oleh rancangan stage dan fitur/elemen music namun tidak mendominasi.

\subsubsection{Personalization}

Dinilai dari keterlibatan partisipasi komunitas dalam taman, rancangan Taman Musik dilengkapi dengan beberapa fitur dapat dikatakan mewakili identitas tematik sebagai taman. Interaksi komunitas dilakukan oleh para pelajar yang bersekolah di sekitar taman dan anak-anak (lihat gambar 5). 

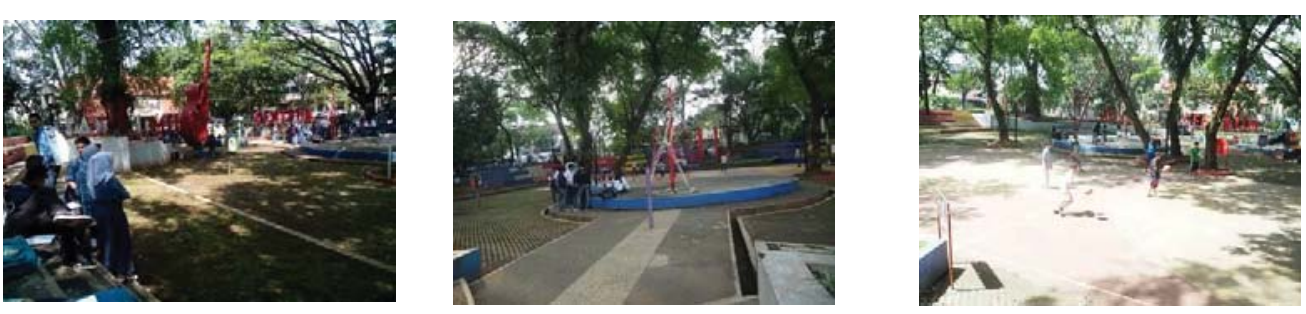

Gambar 5 Penilaian Personalization Taman Musik

Aktifitas yang terjadi berdasarkan hasil pengamatan seperti gambar di atas, didominasi oleh aktifitas mengobrol, duduk, berolahraga dan menikmati suasana. Dominasi titik kumpul terjadi khususnya pada zona amphitheater/ area duduk,sebagaimana dapat dilihat pada gambar 5.

Dari analisis di atas, penamaan Taman Musik dengan tema musik dan diharapkan menjadi tempat pengembangan wahana bermusik memberikan dampak identitas rancangan. Dalam rancangan terwakili dengan adanya fitur/elemen alat music, stage dan amphitheater sebagai visual appropriate. Identitas sebagai taman dan tema "Musik' direspon dengan baik fungsi minimal taman secara umum sebagai pembentuk iklim mikro, tempat mengobrol, duduk, berolahraga dan ragam kegiatan lain, terindikasi pada kriteria robutness. Kekurangan dari rancangan Taman Musik adalah belum dapat memberikan stimulant yang significant pada aktifitas komunitas kota untuk melakukan aktifitas bermusik. Penilaian ini, terlihat pada penilaian disain dari sisi personalization yang membentuk respon aktifitas yang terjadi di Taman. Hasil observasi, taman ini dinilai lebih tersegmentasi untuk kalangan pelajar yang bersekolah di daerah sekitar.

\subsection{Respons Aktifitas Komunitas}

Data yang diamati berupa jumlah pengunjung, segmen umur dan area favorit (lihat tabel 1) yang akan dianalisis untuk mendapatkan segmentasi pengunjung dan zona yang direspon terbaik oleh komunitas. Untuk segmentasi pengunjung, peneliti membagi 4 (empat) kategori umur yaitu: (1) Anak-anak (0-12 thn), (2) Pemuda/i (12-21 thn), (3) Dewasa (21-40 thn), (4) Lansia (40-60 thn).

\section{Tabel 1 Hasil Observasi Pengunjung}

\begin{tabular}{|c|c|c|c|c|c|c|c|c|c|c|c|}
\hline \multirow[b]{2}{*}{ No } & \multirow[b]{2}{*}{$\begin{array}{l}\text { Tanggal } \\
\text { Observasi }\end{array}$} & \multirow[b]{2}{*}{$\begin{array}{l}\text { Waktu } \\
\text { (wib) }\end{array}$} & \multicolumn{4}{|c|}{$\begin{array}{l}\text { Jumlah Pengunjung } \\
\text { (orang) }\end{array}$} & \multicolumn{4}{|c|}{$\begin{array}{l}\text { Segmen Umur } \\
\text { paling Aktif }\end{array}$} & \multirow[t]{2}{*}{ Area Favorit } \\
\hline & & & $\begin{array}{l}\Xi \\
\stackrel{\Xi}{ \pm} \\
\frac{1}{0}\end{array}$ & $\begin{array}{l}\Xi \\
\Xi \\
\grave{ } \\
\stackrel{\Xi}{\Xi}\end{array}$ & 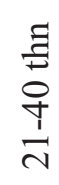 & 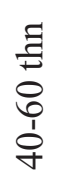 & 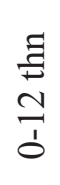 & 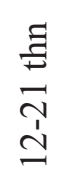 & 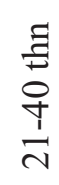 & $\begin{array}{l}\Xi \\
\Xi \\
8 \\
8 \\
\dot{d} \\
\dot{q}\end{array}$ & \\
\hline 1 & 26 Juli 2016 & 13.3 & 0 & 4 & 2 & 2 & & $\mathrm{x}$ & & & area duduk \\
\hline 2 & 27 Juli 2016 & 13.15 & 3 & 8 & 4 & 3 & & $\mathrm{x}$ & & & area duduk \\
\hline 3 & 28 Juli 2016 & 15.57 & 10 & 34 & 6 & 0 & & $\mathrm{x}$ & & & area duduk \\
\hline 4 & 29 Juli 2016 & 11.50 & 0 & $>100$ & 5 & 0 & & $\mathrm{x}$ & & & area duduk \\
\hline 5 & $\begin{array}{l}30 \text { Juli } 2016 \\
\text { (pagi) }\end{array}$ & 10.05 & 0 & 17 & 4 & 2 & & $\mathrm{x}$ & & & panggung tengah \\
\hline 6 & $\begin{array}{l}30 \text { Juli } 2016 \\
\text { (sore) }\end{array}$ & 16.35 & 0 & 17 & 6 & 0 & & $\mathrm{x}$ & & & $\begin{array}{l}\text { area duduk, aera } \\
\text { lapangan }\end{array}$ \\
\hline 7 & $\begin{array}{l}31 \text { Juli } 2016 \\
\text { (pagi) }\end{array}$ & 10.42 & 4 & 20 & 16 & 0 & & $\mathrm{x}$ & & & area duduk \\
\hline 8 & $\begin{array}{l}31 \text { Juli } 2016 \\
\text { (sore) }\end{array}$ & 16.47 & 11 & 16 & 3 & 0 & $\mathrm{x}$ & $\mathrm{x}$ & & & area duduk \\
\hline 9 & 1 Agustus 2016 & 12.10 & 2 & 3 & 7 & 2 & & & $\mathrm{x}$ & & area duduk \\
\hline
\end{tabular}


Dari sisi segmen umur yang paling aktif diidentifikasi sesuai dengan tema yang mengarah ke segmentasi pengunjung remaja. Fakta ini menandakan bahwa fitur/elemen dalam taman telah memberikan stimulus yang sesuai dan direspon oleh komunitas remaja secara baik dengan melakukan kegiatan aktif seperti duduk dan berbincang. Kegiatan ini berkesesuaian dengan fungsi taman sebagai area publik yaitu minimal memberikan tempat untuk beraktivitas berbincang, duduk dan melihat. Zona amphitheater dan zona main basket, memberikan stimulan yang direspon secara dominan oleh pengunjung dengan aktivitas yang sesuai. Hal ini sejalan dengan pendapat area favorit yaitu zona amphiteather (area duduk). Taman ini belum dapat difungsikan secara aktif dalam hal kesesuaian aktivitas dengan tema -identitasnya sebagai taman Musik.

Peneliti juga melakukan pengambilan data untuk tujuan responden ke taman, untuk mendapatkan gambaran tentang tujuan responden dan kesesuaian rancangan taman atau apakah respon aktifitas pengunjung sesuai dengan identitas taman seperti ditunjukkan pada Gambar 6

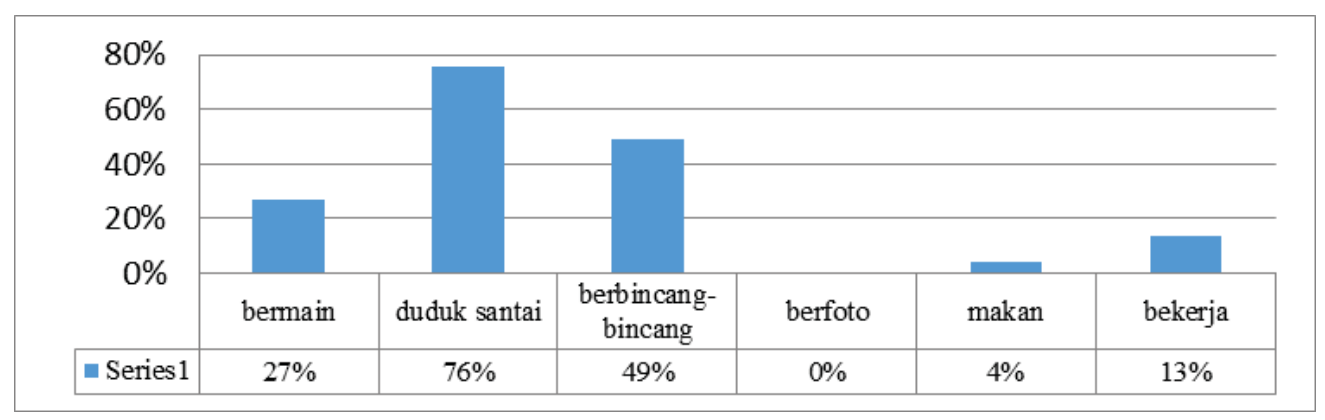

Gambar 6. Diagram tujuan pengunjung Taman Musik

Dari diagram 1 di atas diketahui bahwa $76 \%$ tujuan pengunjung adalah untuk duduk santai di taman. Tergambarkan bahwa respons pengunjung yang tidak sesuai dengan tema dari Taman yaitu bermain musik. Hasil observasi dapat dilihat pada Gambar 7.

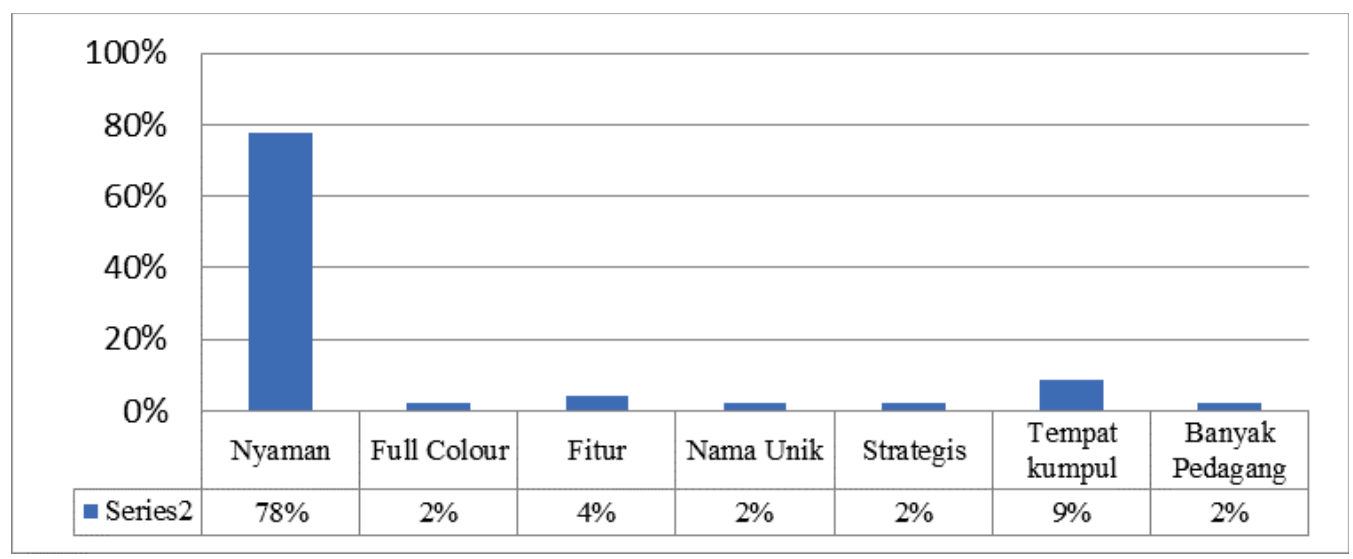

Gambar 7 Penilaian pengunjung/responden pada rancangan taman

Dari hasil tersebut didapatkan sekitar 78\% menjawab faktor kenyamanan dan peringkat kedua 9\% adalah tempat yang menyenangkan untuk berkumpul. Komunitas kota sebagai pengunjung, menilai Taman Musik merupakan taman yang nyaman dan tempat berkumpul. Hal ini sejalan dengan penelitian di taman tematik lainnya dengan studi kasus berbeda yaitu Taman Lansia [8], dimana responden menilai sisi positif taman lainnya adalah dari sisi kenyamanan. 


\section{KESIMPULAN}

Taman Musik menyediakan fitur/elemen yang sesuai dengan identitas-tema "Musik" secara minimal. Secara visual appropriate, rancangan penampil identitas terwakili dengan baik oleh beberapa fitur. Kenyamanan taman dinilai oleh responden sebagai alasan untuk datang ke taman tersebut. Untuk kriteria comfort and image, sudah memenuhi. Namun dari rancangan belum dapat memberikan stimulus yang sesuai. rancangan fitur tersebut hanya direspon oleh pengunjung berupa aktifitas pada umumnya yaitu duduk dan berkumpul, tidak secara khusus yaitu bermain musik. Sehingga dari sisi uses and activity tidak berkesesuaian dengan tema.

\section{DAFTAR PUSTAKA}

[1] Carr, S., Francis, M., Rivlin, L.G., Stone, A.M. 1995. Public Spaces. Cambridge University Press.

[2] Carmona, Matthew, and Heath, Tim. 2003. Public Places - Urban Spaces. London. Architectural Press.

[3] Rencana Pembangunan Jangka Menengah Daerah Kota Bandung Tahun 2013- 2018, 2013, Bappeda Kota Bandung

[4] Marcos L. Rosa, 2012, Hand made urbanism, From Community Innitiatives To Participatory Model, UTE E. WEILAND (ED)

[5] Virdianti, 2015, Rancangan Berbasis Komunitas Pada Fitur Dominan dan Penyelenggaraan Taman Tematik Kota Bandung, publikasi dalam Prosiding Seminar Nasional "Rekayasa dan Desain", December 1-2, 2015

[6] Bentley, Ian.et all, 2001,Responsive Environment - A Manual For Designers, Architectural Press, Oxford.

[7] http://www.disparbud.jabarprov.go.id/wisata/destdet.php?id=1085\&lang=id di akses 4 agustus 2016

[8] Virdianti, Duhita, 2016, Investigating The Theme, Culture Life-Style and Innovation of The Integrated Design of Lansia Park, publikasi dalam Prosiding "The Third International Conference on Creatives Industries", November 14-15, 2016.

[9] https://www.google.com/search?q=taman+sma+5+bandung + photos\&client=firefoxb\&biw $=1280 \&$ bih $=663 \&$ tbm $=$ isch \&tbo $=u \&$ source $=$ univ\&sa $=X \& v e d=0$ ahUKEwjvmufezvvOAhVFto $8 \mathrm{KHbJNB}$ FMQsAQIGw\#imgrc=YJbv9S8e3zZ-SM\%3A/diakses 6 September 2016 